\title{
Exposure to sheep dip and the incidence of acute symptoms in a group of Welsh sheep farmers
}

Huw Rees

\begin{abstract}
Objectives-To measure the exposure of a group of farmers to organophosphate pesticide in sheep dip, and to record the incidence of symptoms after exposure.

Design-A prospective study of the autumn 1992 dipping period. Working methods were assessed by questionnaire. Absorption of organophosphate pesticide was estimated before, immediately after, and six weeks after dipping by measuring plasma cholinesterase, erythrocyte cholinesterase, and dialkylphosphate urinary metabolites of organophosphates. Symptoms were recorded by questionnaire at the same time as biological monitoring. Possible confounding factors were identified by medical examination of the subjects.
\end{abstract}

Setting-Three community council electoral wards in Powys, typical of hill sheep farming areas in Wales.

Subjects-All (38) men engaged in sheep dipping living in the three community council electoral wards.

Results-23 sheep farmers and one dipping contractor completed the study-a response rate of $63 \%$. A sample of seven men who refused to enter the full study had similar working practices to the 24 subjects. Subjects reported inadequate handling precautions, and significant skin contamination with dip. Two men reported under diluting dip concentrate for use. Both had significant depression of erythrocyte cholinesterase after dipping. This indicated some absorption of organophosphate pesticide-but this did not reach levels usually associated with toxicity. It was not clear whether the symptoms of these two mens were caused by organophosphate exposure. Measurement of dialkylphosphate urinary metabolites in a single specimen of urine voided shortly after the end of dipping could not be correlated with individual exposure.

Conclusions-Sheep dipping is strenuous and dirty work and sheep farmers find it difficult to wear personal protective equipment and avoid skin contamination with dip. In this limited study, farmers did not seem to have significant organophosphate toxicity, despite using inadequate handling precautions.

(Occup Environ Med 1996;53:258-263)
Keywords: cholinesterase inhibitors; organophosphate insecticides; occupational diseases

Sheep are prone to infestation with a variety of skin parasites which can kill the animal or reduce sale value. In the United Kingdom, most farmers dip (totally immerse) all or a portion of their sheep in insecticide twice a year to control ectoparasites. This is strenuous and dirty work and it is difficult to avoid skin contamination. Users are advised to wear impervious clothing for protection. ${ }^{1}$

The toxicity of sheep dip could be related to the concentration and toxicity of the insecticide, the formulants, and antibacterial agents like phenol and epichlorhydrin. Since this study, phenol has been withdrawn from most sheep dips.

At the time of the study, sheep dips contained one of three organophosphate compounds: diazinon or propetamphos (both classed as moderately toxic), or chlorfenvinphos (highly toxic). ${ }^{2}$ Diazinon and propetamphos are inactive thion compoundsactivation occurs in vivo, by conversion to oxon compounds in the liver. Organophosphates have two main toxic effects, cholinesterase inhibition at neuronal synapses and organophosphate induced delayed peripheral neuropathy. ${ }^{3}$ Symptoms of acute poisoning are consistent with the pharmacological model of cholinesterase inhibition, ${ }^{4}$ but can be mimicked by anxiety, cigarette smoking, or alcohol. ${ }^{5}$

Diazinon $^{6}$ and chlorfenvinphos ${ }^{7}$ do not cause delayed neuropathy. Organophosphates causing delayed neuropathy have been identified in animal experiments and have apparently been excluded from agricultural use in the United Kingdom. ${ }^{3}$

Senanayake and Karalliedde have coined the term intermediate syndrome for distinct symptoms and signs appearing after the cholinergic phase; but before the time interval expected for delayed neuropathy. ${ }^{8}$ The skin is the most important route of absorption for sheep dip organophosphates. ${ }^{9}$

\section{Methods}

MEASURING EXPOSURE TO ORGANOPHOSPHATES Absorption of organophosphate pesticides is estimated by measuring changes in plasma and erythrocyte cholinesterase concentrations. These are indirect measures of the effects of organophosphates on cholinesterase at synapses. Erythrocyte cholinesterase is thought 
to be a better index than plasma cholinesterase. Both enzymes show wide variation between and within individual people. Both these variations are larger for the plasma enzyme. ${ }^{5}$

Significant changes are identified by measuring enzyme concentrations in the same person before and after exposure to organophosphates. The Health and Safety Executive (HSE) recommend an interval of 60 days between measurement of baseline plasma cholinesterase and previous organophosphate exposure. ${ }^{10}$

In the laboratory used in this study differences between successive estimations that are considered to be significant are plasma cholinesterase $15 \%$ and erythrocyte cholinesterase $10 \% .{ }^{11}$ These figures represent a combination of variation within the subjects and analytical imprecision.

The relation between symptoms and falls in cholinesterase is variable. The HSE recommends that a fall of $30 \%$ or more in plasma cholinesterase requires a medical examination; and consideration of withdrawal from work. ${ }^{10}$ For the sake of simplicity, the figure of $30 \%$ is applied to changes in both plasma and erythrocyte cholinesterase. ${ }^{5}$

The relation between symptoms and changes in cholinesterase concentrations can be further confounded by the development of tolerance. Workers regularly exposed to organophosphates may have large falls in plasma cholinesterase without symptoms. ${ }^{5}$ Several investigators have attempted to monitor exposure by measuring urinary excretion of dialkylphosphate metabolites of organophosphates. Concentrations of urinary metabolites in exposed groups as opposed to individual workers have been correlated with the quantity of pesticide used. ${ }^{12}$

SUBJECTS

The farmers in the area dipped at different times. This presented considerable logistic difficulties, which limited the size of the study group. The target population consisted of all men engaged in sheep dipping who lived in three adjacent community council electoral wards in Powys. These were initially identified from lists provided by the Wool Marketing Board. All farmers who undertook dipping were then identified by local enquiry. Three smallholders who kept and dipped 20 or less sheep were excluded from the study. Informed, written consent was obtained, and the study was approved by the Powys Local Research Ethics Committee. The area is cool and wet, and supports both hill and lowland types of farming. The amount of arable land is relatively small, and the farmers in the study undertook little or no crop farming. Population movement into and out of the farming community is very limited. The study area is typical of sheep farming areas in Wales.

MEASURING EXPOSURE TO SHEEP DIPBIOLOGICAL MONITORING

This comprised measurement of plasma and erythrocyte cholinesterase concentrations and six urinary dialkylphosphate metabolites of organophosphate pesticides. This was undertaken before dipping, as soon as possible after the end of dipping, and six weeks after the end of dipping.

The single dipping contractor in the study was exposed to dip continuously between May and September 1992-that is, before the start of the study. His baseline cholinesterase concentrations (and symptoms) were recorded 90 days after the end of dipping.

Contamination of blood samples by residual pesticide on the skin is a potential problem. ${ }^{13}$ Before blood sampling the skin was cleaned with Medi-Swabs $\mathrm{H}$ (these contain $70 \%$ isopropyl alcohol $\mathrm{v} / \mathrm{v}$ and $0.5 \%$ chlorhexidine acetate BP). Three millilitres of blood for cholinesterase estimation was collected in Vacutainer tubes containing $7 \cdot 5 \%$ ethylene diamine tetra-acetic acid (EDTA). Subjects were instructed to void a single specimen of

Table 1 Changes in cholinesterase concentrations during dipping

\begin{tabular}{|c|c|c|c|c|c|c|}
\hline \multirow[b]{2}{*}{$\begin{array}{l}\text { Subject } \\
\text { No }\end{array}$} & \multicolumn{3}{|c|}{ Plasma cholinesterase } & \multicolumn{3}{|c|}{ Erythrocyte cholinesterase } \\
\hline & $\begin{array}{l}\text { Before } \\
\text { dipping } \\
\text { (daUil) }\end{array}$ & $\begin{array}{l}\text { Immediately } \\
\text { after dipping } \\
\text { (daU/l) }\end{array}$ & $\begin{array}{l}6 \text { Weeks after } \\
\text { dipping } \\
\text { (daU/l) }\end{array}$ & $\begin{array}{l}\text { Before } \\
\text { dipping } \\
(h U / l)\end{array}$ & $\begin{array}{l}\text { Immediately } \\
\text { after dipping } \\
\text { (hU/l) }\end{array}$ & $\begin{array}{l}6 \text { Weeks after } \\
\text { dipping } \\
\text { (hU/l) }\end{array}$ \\
\hline $\begin{array}{r}1 \\
2 \\
3 \\
4 \\
5 \\
6 \\
7 \\
8 \\
9 \\
10 \\
11 \\
12 \\
13 \\
14 \\
15 \\
16 \\
17 \\
18 \\
19 \\
20 \\
21 \\
22 \\
23\end{array}$ & $\begin{array}{l}259 \\
308 \\
247 \\
322 \\
295 \\
314 \\
408 \\
269 \\
252 \\
232 \\
188 \\
265 \\
278 \\
311 \\
375 \\
345 \\
207 \\
251 \\
296 \\
341 \\
314 \\
361 \\
362\end{array}$ & $\begin{array}{l}262 \\
367 \\
250 \\
324 \\
270 \\
316 \\
407 \\
291 \\
264 \\
221 \\
189 \\
257 \\
250 \\
283 \\
381 \\
316 \\
219 \\
261 \\
255 \\
310 \\
290 \\
356 \\
345\end{array}$ & $\begin{array}{l}282 \\
352 \\
240 \\
374 \\
313 \\
310 \\
376 \\
290 \\
273 \\
237 \\
180 \\
295 \\
297 \\
322 \\
348 \\
366 \\
195 \\
288 \\
298 \\
319 \\
277 \\
345 \\
342\end{array}$ & $\begin{array}{l}177 \\
190 \\
160 \\
187 \\
144 \\
170 \\
173 \\
138 \\
160 \\
148 \\
190 \\
168 \\
164 \\
160 \\
167 \\
161 \\
176 \\
131 \\
187 \\
167 \\
202 \\
174 \\
170\end{array}$ & $\begin{array}{l}164 \\
193 \\
160 \\
200 \\
172 \\
171 \\
209 \\
141 \\
169 \\
158 \\
176 \\
198 \\
183 \\
166 \\
189 \\
188 \\
167 \\
190 \\
209 \\
186 \\
203 \\
165 \\
125\end{array}$ & $\begin{array}{l}179 \\
196 \\
155 \\
201 \\
159 \\
163 \\
173 \\
136 \\
162 \\
148 \\
205 \\
193 \\
165 \\
172 \\
175 \\
164 \\
172 \\
193 \\
185 \\
173 \\
191 \\
168 \\
158\end{array}$ \\
\hline 24 & 344 & 338 & 190 & 153 & & \\
\hline
\end{tabular}


Table 2 Changes in cholinesterase concentrations and symptoms

\begin{tabular}{|c|c|c|c|c|c|c|}
\hline $\begin{array}{l}\text { Subject } \\
\text { no }\end{array}$ & $\begin{array}{l}\text { PCHE } \\
\text { d } 1-2 \\
\%\end{array}$ & $\begin{array}{l}E C H E \\
d 1-2 \\
\%\end{array}$ & $\begin{array}{l}\text { New symptoms during } \\
\text { or within } 24 \text { hours } \\
\text { of the end of dipping }\end{array}$ & $\begin{array}{l}\text { PCHE } \\
\text { d } 1-3 \\
\%\end{array}$ & $\begin{array}{l}E C H E \\
d 1-3 \\
\%\end{array}$ & $\begin{array}{l}\text { New symptoms occurring } \\
1-6 \text { weeks after the } \\
\text { end of dipping }\end{array}$ \\
\hline $\begin{array}{l}1 \\
2 \\
3\end{array}$ & $\begin{array}{l}+1 \\
+19 \\
+1\end{array}$ & $\begin{array}{l}-7 \\
+2 \\
0\end{array}$ & $\begin{array}{l}\text { Increasing coryza } \\
\text { Urinary frequency }\end{array}$ & $\begin{array}{l}+9 \\
+14 \\
-3\end{array}$ & $\begin{array}{l}+1 \\
+3 \\
-3\end{array}$ & $\begin{array}{l}\text { Hoarseness } \\
\text { Muscle fasciculation }\end{array}$ \\
\hline 4 & +1 & +7 & & +16 & +7 & $\begin{array}{l}\text { Hoarseness } \\
\text { Sore throat } \\
\text { Coryza }\end{array}$ \\
\hline $\begin{array}{l}5 \\
6 \\
7\end{array}$ & $\begin{array}{l}-8 \\
+1 \\
0\end{array}$ & $\begin{array}{l}+19 \\
+21 \\
+21\end{array}$ & $\begin{array}{l}\text { Urinary frequency } \\
\text { Dry cough }\end{array}$ & $\begin{array}{l}+6 \\
-1 \\
-8\end{array}$ & $\begin{array}{l}+10 \\
-4 \\
0\end{array}$ & Mouth ulcers \\
\hline $\begin{array}{r}8 \\
9 \\
10\end{array}$ & $\begin{array}{l}+8 \\
+5 \\
-5\end{array}$ & $\begin{array}{l}+2 \\
+6 \\
+7\end{array}$ & $\begin{array}{l}\text { Diarrhoea } \\
\text { Faecal incontinence } \\
\text { Incoordination } \\
\text { Insomnia }\end{array}$ & $\begin{array}{l}+8 \\
+8 \\
+2\end{array}$ & $\begin{array}{l}-1 \\
+1 \\
0\end{array}$ & $\begin{array}{l}\text { Abdominal pain } \\
\text { Dry cough }\end{array}$ \\
\hline 11 & +1 & -7 & & -4 & +8 & $\frac{\text { Increased muscle }}{\text { fasciculation }}$ \\
\hline $\begin{array}{l}12 \\
13 \\
14\end{array}$ & $\begin{array}{l}-3 \\
-10 \\
-9\end{array}$ & $\begin{array}{l}+18 \\
+12 \\
+4\end{array}$ & $\begin{array}{l}\text { (Fall in peak flow rate) } \\
\text { Sore throat } \\
\text { Eye pain } \\
\text { Headache }\end{array}$ & $\begin{array}{l}+11 \\
+7 \\
+4\end{array}$ & $\begin{array}{l}+15 \\
+1 \\
+8\end{array}$ & $\begin{array}{l}\text { Increased mouth ulcers } \\
\text { Dizziness }\end{array}$ \\
\hline 15 & +2 & +13 & $\frac{\text { Hot flush }}{\text { Coryza }}$ & -7 & +5 & Dry cough \\
\hline 16 & -8 & +17 & Mouth ulcers & +6 & +2 & $\begin{array}{l}\text { Sore throat } \\
\text { Coryza }\end{array}$ \\
\hline 17 & +6 & -5 & & -6 & -2 & $\begin{array}{l}\text { Increasing coryza } \\
\text { Urinary frequency } \\
\text { Abdominal pain }\end{array}$ \\
\hline $\begin{array}{l}18 \\
19\end{array}$ & $\begin{array}{l}+4 \\
-14\end{array}$ & $\begin{array}{l}+45 \\
+12\end{array}$ & & $\begin{array}{l}+15 \\
+1\end{array}$ & $\begin{array}{l}+47 \\
-1\end{array}$ & $\begin{array}{l}\text { Increasing productive cough } \\
\text { Coryza } \\
\text { Face pain } \\
\text { Dry mouth } \\
\text { Mouth ulcers } \\
\text { Increasing constipation } \\
\text { Sore tongue } \\
\text { Paraesthesiae }\end{array}$ \\
\hline 20 & -9 & +11 & $\begin{array}{l}\text { Dyspnoea } \\
\text { Wheeze }\end{array}$ & -6 & +4 & Arthralgia \\
\hline 21 & -8 & 0 & $\begin{array}{l}\text { Malaise } \\
\text { Diarrhoea }\end{array}$ & -12 & -5 & $\begin{array}{l}\text { Mouth ulcers } \\
\text { Insomnia }\end{array}$ \\
\hline 22 & -1 & -5 & Hunger & -4 & -3 & $\frac{\text { Malaise }}{\text { Abdominal pain }}$ \\
\hline 23 & -5 & -26 & $\begin{array}{l}\text { Coryza } \\
\text { Increased lacrimation } \\
\text { Headache }\end{array}$ & -6 & -7 & $\begin{array}{l}\text { Sialorrhoea } \\
\text { Headache }\end{array}$ \\
\hline 24 & -2 & -19 & $\begin{array}{l}\text { Dyspnoea } \\
\text { Wheeze } \\
\text { Cold extremities } \\
\text { Joint tenderness } \\
\text { Terminal dribbling } \\
\text { Thirst } \\
\text { Weight loss } \\
\text { Diarthoea } \\
\text { Bloody stool } \\
\text { Eye pain } \\
\text { Tremor } \\
\text { Altered sense of smell }\end{array}$ & & & $\begin{array}{l}\text { Data on symptoms not } \\
\text { presented because blood } \\
\text { specimens were spoiled. }\end{array}$ \\
\hline
\end{tabular}

Symptoms underlined can be caused by organophosphate toxicity.

PCHE dl-2 = Difference between plasma cholinesterase concentrations before and immediately after dipping.

ECHE dl-2 = Difference between erythrocyte cholinesterase concentrations before and immediately after dipping.

PCHE dl-3 = Difference between plasma cholinesterase concentrations before and 6 weeks after dipping.

ECHE dl-3 = Difference between erythrocyte cholinesterase concentrations before and 6 weeks after dipping.

urine for dialkylphosphate estimation into a 20 $\mathrm{ml}$ Sterilin universal container. The specimen was collected as soon as possible after the end of dipping.

Specimens were analysed at the HSE Occupational Medicine and Hygiene Laboratory, Sheffield. Plasma and erythrocyte cholinesterase concentrations were measured with an automated, discrete, kinetic version of Ellmans' spectrophotometric method. ${ }^{14} 15$

Urine was analysed for dialkylphosphate metabolites with high resolution gas chromatography, with flame photometric detection. ${ }^{116}$ Six metabolites were assayed:

dimethylphosphate (DMP)

diethylphosphate (DEP)

dimethylthiophosphate (DMTP)

diethylthiophosphate (DETP)

dimethyldithiophosphate (DMDTP)

diethyldithiophosphate (DEDTP)
QUESTIONNAIRES ON WORKING METHODS AND SYMPTOMS

Subjects were visited at home as soon as possible after dipping and a questionnaire on working methods was answered. Analysis of all questionnaires was completed before examining the results of the biological monitoring.

Subjects were seen at home on three occasions to answer a questionnaire on symptoms and medical history. This was at the same time as biological monitoring. Before dipping, symptoms experienced during the preceding four weeks were recorded. As soon as possible after the end of dipping, symptoms experienced since the start of dipping were recorded. Six weeks after the end of dipping, symptoms experienced since dipping were recorded. Analysis of all questionnaires was completed before examining the results of the biological monitoring. 
Table 3 Intervals between exposure to dip, blood sampling, and laboratory analysis

\begin{tabular}{|c|c|c|c|c|c|c|c|}
\hline \multirow[b]{2}{*}{ Subject No } & \multicolumn{7}{|c|}{ Interval between } \\
\hline & $\begin{array}{l}\text { Summer } \\
\text { dip and } \\
\text { sample } \\
\text { before } \\
\text { exposure } \\
\text { (days) }\end{array}$ & $\begin{array}{l}\text { Sample } \\
\text { before } \\
\text { exposure } \\
\text { and second } \\
\text { sample } \\
\text { (days) }\end{array}$ & $\begin{array}{l}\text { Start of } \\
\text { dip and } \\
\text { second } \\
\text { sample } \\
\text { (days) }\end{array}$ & $\begin{array}{l}\text { End of } \\
\text { dip and } \\
\text { second } \\
\text { sample } \\
\text { (days) }\end{array}$ & $\begin{array}{l}\text { Second } \\
\text { sample } \\
\text { and lab } \\
\text { analysis } \\
\text { (days) }\end{array}$ & $\begin{array}{l}\text { End of } \\
\text { dip and } \\
\text { third } \\
\text { sample } \\
\text { (days) }\end{array}$ & $\begin{array}{l}\text { Third } \\
\text { sample } \\
\text { and lab } \\
\text { analysis } \\
\text { (days) }\end{array}$ \\
\hline 1 & 30 & 42 & 1 & $<1$ & 2 & 39 & 2 \\
\hline 2 & 30 & 43 & 7 & 1 & $\overline{6}$ & 39 & 2 \\
\hline 3 & 33 & 48 & 1 & $<1$ & 1 & 43 & 2 \\
\hline 4 & 56 & 36 & 1 & $<1$ & 1 & 35 & 2 \\
\hline 5 & 48 & 36 & 1 & $<1$ & 1 & 35 & 2 \\
\hline 6 & 80 & 48 & i & i & 1 & 42 & 1 \\
\hline 7 & 54 & 54 & 18 & $<1$ & 1 & 43 & i \\
\hline 8 & NA & 41 & 1 & $<1$ & 2 & 40 & 2 \\
\hline 9 & 117 & 19 & $<1$ & $<1$ & 2 & 41 & 1 \\
\hline 10 & 54 & 9 & 3 & $<1$ & 1 & 39 & 1 \\
\hline 11 & 66 & 7 & 1 & $<1$ & 1 & 39 & 1 \\
\hline 12 & 69 & 6 & 2 & 2 & 2 & 41 & 4 \\
\hline 13 & 23 & 6 & 2 & 2 & 2 & 41 & 4 \\
\hline 14 & NA & 3 & $<1$ & $<\overrightarrow{1}$ & $\overline{1}$ & 45 & 1 \\
\hline 15 & NA & 21 & 18 & $<1$ & 2 & 55 & 2 \\
\hline 16 & 23 & 6 & 2 & 2 & 2 & 41 & 4 \\
\hline 17 & NA & 62 & $<1$ & $<1$ & 1 & 77 & i \\
\hline 18 & 56 & 4 & 2 & 1 & 2 & 43 & 1 \\
\hline 19 & NA & 4 & 1 & 1 & 2 & 43 & i \\
\hline 20 & NA & 34 & $<1$ & $<1$ & 1 & 43 & 2 \\
\hline 21 & 60 & 9 & $<1$ & $<1$ & 1 & 44 & 2 \\
\hline 22 & 104 & 21 & 1 & $i$ & $i$ & 42 & 1 \\
\hline 23 & 55 & 7 & 1 & $<1$ & 6 & 38 & 2 \\
\hline 24 & 90 & & 4 Months & 8 & 1 & & \\
\hline
\end{tabular}

NA = not applicable - the farmers did not undertake a summer dip.

The interval between the blood sampling before exposure and laboratory analysis was one day in all cases.

IDENTIFYING CONFOUNDING FACTORS

Several confounding factors were measured at the same time as the biological monitoring, because the monitoring is indirect and open to confounding by many things-for example anaemia, liver disease, acute infection, chronic debilitating disease, and drug treatments. ${ }^{251217-21}$ Existing symptoms, diseases, medications, and cigarette smoking were identified by: the questionnaire on symptoms and medical history, physical examination before dipping, full blood count, reticulocyte count, liver function tests, stick urinalysis, and measurement of peak flow rate. Urine was tested for protein, glucose, etc with BM-Test-5L sticks. Peak flow rates were measured with a Wright Peak Flow Mini-Meter. Recent (less than 60 days) and current chemical exposure from sources other than sheep dip were identified by questionnaire.

\section{Results}

During the study period 38 men undertook dipping in the three wards. Twenty three farmers and one dipping contractor agreed to enter the study, giving a response rate of $63 \%$. The mean (range) age of the subjects was 50 (17-80) years. The mean (range) time spent farming was 34 (3-36) years. The mean (range) time spent dipping sheep was 31 (3-66) years.

Seven subjects refused to enter the full study, but answered the questionnaire on practices of occupational hygiene. The mean age and working practices of this sample were similar to those of the study group.

Subjects 23 (a sheep farmer) and 24 (the dipping contractor) had significant falls in erythrocyte cholinesterase activity after dipping. Neither reached the level of $30 \%$ usually associated with hazard. Both subjects reported under diluting dip concentrate for use. Subjects were asked direct questions about 90 different symptoms. Forty seven of these can be caused by organophosphate toxicity (these are underlined in table 2). The symptoms listed either occurred for the first time after dipping, or became worse after dipping; and could not be attributed to another obvious cause. Chronic symptoms, and symptoms which occurred in the month before the initial questionnaire were discounted from the analysis.

Table 3 lists the time intervals between exposure to sheep dip, blood sampling, and sample analysis: all of which can confound biological monitoring. Separate analysis found no relation between symptoms and age, tobacco smoking, alcohol consumption, complaints of an overpowering smell, or attribution by the subject of symptoms to sheep dip. The cholinergic symptoms of subjects 8,11 , and 20 could be related to medication or preexisting medical conditions.

Subject 24 had a marginal reticulocytosis when baseline erythrocyte cholinesterase activity was measured. This may have raised the baseline enzyme activity (it lies in the upper range of values), giving a spurious fall after dipping. ${ }^{14}$

Table 4 shows that urinary excretion of dialkylphosphate metabolites was an inconsistent measure of individual exposure to organophosphate pesticide. Analysis also did not show a relation between the concentration of urinary metabolites and the date of dipping, the quantity of organophosphate used, the number of sheep dipped, working practices, and reported contamination.

Each farmer dipped a mean (range) of 913 (70-3400) sheep over a period of several days. All used "short swim" rectangular dipping pits. Fourteen used propetamphos dips and 10 used diazinon dips (one used both).

Most reported contamination of skin or 
Table 4 Urinary concentrations of dialkylphosphate metabolites (units $=$ nmol/mmol creatinine)

\begin{tabular}{|c|c|c|c|c|c|c|c|c|c|c|c|c|}
\hline \multirow{2}{*}{$\begin{array}{l}\text { Subject } \\
\text { No }\end{array}$} & \multicolumn{4}{|c|}{ Before dip } & \multicolumn{4}{|c|}{ After dip } & \multicolumn{4}{|c|}{6 weeks after dip } \\
\hline & $D M P$ & $D M T P$ & $D E P$ & $D E T P$ & $D M P$ & DMTP & $D E P$ & DETP & $D M P$ & $D M T P$ & $D E P$ & DETP \\
\hline $1^{\star}$ & 0 & 0 & 0 & 0 & 0 & 20 & 10 & 40 & 5 & 0 & 0 & 0 \\
\hline $2^{\star}$ & 8 & 8 & 4 & 0 & 15 & 22 & 5 & 0 & 0 & 0 & 4 & 0 \\
\hline 3 & 0 & 0 & 0 & 0 & 0 & 0 & 0 & 0 & 0 & 0 & 0 & 0 \\
\hline 4 & 7 & 0 & 13 & 0 & 0 & 0 & 5 & 0 & 7 & 0 & 6 & 0 \\
\hline 5 & 26 & 0 & 16 & 0 & 11 & 0 & 0 & 0 & 9 & 0 & 3 & 0 \\
\hline $6^{\star}$ & 0 & 29 & 12 & 11 & 0 & 0 & 0 & 0 & 0 & 0 & 0 & 0 \\
\hline 7 & 8 & 0 & 0 & 0 & 10 & 0 & 0 & 0 & 29 & 8 & 3 & 0 \\
\hline 8 & 14 & 0 & 4 & 0 & 0 & 35 & 5 & 0 & 10 & 26 & 10 & 4 \\
\hline 9 & 17 & 0 & 0 & 0 & 0 & 0 & 0 & 0 & 0 & 14 & 0 & 4 \\
\hline 10 & 13 & 0 & 7 & 0 & 0 & 0 & 5 & 5 & 0 & 0 & 0 & 0 \\
\hline $11^{\star}$ & 0 & 0 & 2 & 0 & 0 & 0 & 10 & 15 & 9 & 0 & 6 & 2 \\
\hline $12^{\star}$ & 0 & 0 & 4 & 0 & 7 & 13 & 4 & 2 & 0 & 0 & 7 & 5 \\
\hline $13^{\star}$ & 12 & 13 & 7 & 14 & 7 & 0 & 7 & 6 & 0 & 0 & 0 & 0 \\
\hline 14 & 28 & 0 & 8 & 0 & 11 & 0 & 0 & 0 & 14 & 18 & 4 & 0 \\
\hline 15 & 14 & 0 & 0 & 0 & 16 & 14 & 5 & 0 & 11 & 0 & 5 & 9 \\
\hline $16^{\star}$ & 11 & 12 & 14 & 4 & 0 & 0 & 12 & 6 & 16 & 0 & 0 & 0 \\
\hline $17^{\star}$ & 33 & 35 & 11 & 0 & 8 & 0 & 9 & 17 & 31 & 12 & 0 & 0 \\
\hline 18 & 11 & 0 & 9 & 0 & 0 & 0 & 6 & 0 & 21 & 0 & 9 & 0 \\
\hline $19^{\star}$ & 7 & 0 & 7 & 0 & 12 & 0 & 80 & 14 & 8 & 0 & 19 & 20 \\
\hline 20 & 32 & 0 & 9 & 0 & 13 & 0 & 9 & 6 & 0 & 0 & 7 & 0 \\
\hline 21 & 10 & 0 & 3 & 0 & 11 & 0 & 0 & 0 & 0 & 0 & 11 & 4 \\
\hline $22^{\star}$ & 0 & 0 & 0 & 0 & 0 & 14 & 5 & 5 & 0 & 0 & 4 & 5 \\
\hline 23 & 11 & 0 & 0 & 0 & 0 & 0 & 0 & 0 & 0 & 0 & 0 & 0 \\
\hline 24 & 0 & 0 & 0 & 0 & 12 & 0 & 15 & 4 & 27 & 6 & 7 & 0 \\
\hline
\end{tabular}

*Subjects using diazinon, which is metabolised to DEP and DETP.

clothing with dip. Five subjects reported skin contamination with a few drops of concentrate. Two washed it off immediately, three did so later in day. None of the subjects used adequate personal protective equipment. Many claimed that this was because it was too hot, impaired mobility, and made it difficult to handle the sheep. Few practised adequate decontamination. Disposal of dip was not reported to be a contamination problem. Most men reported storing dip concentrate from one season to the next, but little contamination occurred. Exposure to organophosphate from other pesticide use, or medications was not found. Farmers had good awareness of reporting duties, but poor knowledge of other regulations and suitable working practices. Only one of the subjects reported making an assessment under the Control of Substances Hazardous to Health Regulations.

\section{Discussion}

Plasma and erythrocyte cholinesterase are controlled by different physiological mechanisms. Therefore a reduction in both is a good indication of organophosphate exposure-rather than physiological or other variation. ${ }^{18}$ Diazinon causes larger falls in plasma than erythrocyte cholinesterase. ${ }^{5}$ Plasma cholinesterase usually falls faster after exposure to an organophosphate. ${ }^{12} \mathrm{~A}$ characteristic sequence after exposure to organophosphate pesticide is low plasma cholinesterase followed by low plasma and erythrocyte cholinesterase and finally low erythrocyte cholinesterase and normal plasma enzyme concentrations. ${ }^{5}$

Two subjects had significant falls in erythrocyte cholinesterase concentrations, but it was not clear whether their symptoms were caused by organophosphate exposure. Many of the other subjects had symptoms which might be attributed to organophosphate toxicity, but none had significant falls in cholinesterase concentrations. No new symptoms occurred between two and four days after the end of dipping. Symptoms which occurred for the first time, or became worse between one and six weeks after the end of dipping, were clearly not caused by the acute cholinergic toxicity usually recognised after exposure to organophosphates. ${ }^{2512}$ However, this does not exclude an association with organophosphate exposure in general. Many subjects had symptoms both before and after dipping, which are not presented in the tables. None of the subjects had symptoms or signs of intermediate syndrome, or organophosphate induced delayed peripheral neuropathy.

Cumulative toxicity and tolerance are probably not important for most sheep farmers, because of their intermittent exposure. However, it may be important for dipping contractors.

After the blood sample has been collected a variety of processes can affect the cholinesterase-organophosphate complex in vitro, and confound measurement. ${ }^{5}$ However, diazinon and propetamphos form stable complexes with cholinesterase and there is little or no spontaneous enzyme reactivation. ${ }^{23}$ Diazinon and propetamphos are both inactive sulphon compounds, and further in vitro cholinesterase phosphorylation is unlikely. The HSE recommends that blood should be analysed within 24-48 hours of being taken.

The plasma cholinesterase estimation in subject 24 was confounded by the delay in sampling. For the rest of the blood cholinesterase measurements, careful consideration indicates that they would have allowed detection of significant falls in cholinesterase concentrations. ${ }^{251224}$ As expected, plasma cholinesterase measurements showed a wider variation than erythrocyte cholinesterase. ${ }^{5}$ The plasma cholinesterase concentrations all lie above the lower limit of normal for a healthy population-162 daU/1. ${ }^{15}$

Thirteen samples showed an increase of $10 \%$ or more for erythrocyte cholinesterase: and three samples, an increase of $15 \%$ or more for plasma cholinesterase. These significant increases were unexpected, and may reflect a large confounding error at some point between 
blood sampling and laboratory analysis. For example, subject 18's low initial erythrocyte cholinesterase concentration is clearly a spurious result. Subject 4 developed a raised $\alpha_{2}-$ globulin before his final cholinesterase estimation. This fraction includes plasma cholinesterase and may have contributed to the $16 \%$ increase in plasma enzyme. ${ }^{20}$

The compounds DEP and DETP were found in the urine of farmers who did not handle diazinon-the origin of these metabolites could not be established. Neither could the origin of the DMP and DMTP be identified. Considering the group as a whole, urinary metabolites were a sensitive but non-specific measure of exposure. These results echo the findings of other workers. ${ }^{25}$ Skin absorption prolongs urinary excretion of metabolites, and reliable sampling may require several days. ${ }^{1626} 27$

Farmers complained of difficulty wearing the personal protective equipment recommended for dipping, but this should not prevent the use of adequate protection when diluting the dip concentrate for use.

Significant exposure from dipped sheep or contaminated soil and ground water is unlikely, because organophosphates rapidly degrade in cold wet conditions. However, any sulphotetraethylpyrophosphate contaminating the technical product may be more persistent in the environment. ${ }^{328}$ Chemical byproducts and emulsion separation on storage can increase the toxicity of pesticides. ${ }^{35}$ 29-32. Manufacturers stabilise formulations to prevent this. ${ }^{5}$ However, most subjects in this study stored sheep dip for considerable periods of time-increasing the risk of toxicity.

\section{Conclusions}

This limited study has not provided evidence of acute organophosphate toxicity in sheep dippers, despite inadequate handling procedures. Falls in erythrocyte cholinesterase concentrations in two subjects may have been associated with under diluting dip concentrate for use. Farmers find difficulty with the personal protective equipment recommended for sheep dipping.

Blood cholinesterase and urinary dialkylphosphate measurements were performed by the Health and Safety Executive, Occupational Medicine and Hygiene Laboratory, Sheffield. The research was supported by a grant from the Welsh Scheme for the Development of Health and Social Research (under the aegis of the Welsh Office). I am grateful to the following for their help and advice: Dr D Gompertz, Dr Kerr Wilson, Dr J Cocker, Dr H Mason and Dr B Nutley, Health and Safety Executive; Dr D Coggon, MRC Environmental Epidemiology Unit, University of Southampton; Dr VSG Murray, National Poisons Unit; Dr A Misir, Occupational Health Department, Glan Hafren NHS Trust, Gwent; Dr P Scott, Pathology Department, Nevill Hall Hospital, Gwent; Dr R Newcombe, Department of Medical Computing and Statistics, University Department of Medical Computing and Statistics, University
of Wales College of Medicine, Cardiff; Mr G Titley, Medical of Wales College of Medicine, Cardiff; Mr G Titley, Medical
Librarian, Royal Gwent Hospital, Newport, Gwent; and Dr Librarian, Royal Gwent Hospital, Newport, Gwent; and Dr
HF Thomas, MRC Epidemiology Unit (South Wales), Llandough Hospital, Penarth, South Glamorgan.

1 Health and Safety Executive, Veterinary Medicines Directorate, Department of the Environment. Sheep dipping. London: HSE, 1995. (AS29, rev.)

2 Morgan DP, ed. Recognition and management of pesticide poisonings. Washington: United States Environmenta Protection Agency, Office of Pesticides Programmes, 1982

3 United Nations Environment Programme, Internationa phosphorous insecticides: a general introduction. Geneva: phosphorous insecticides: a general introduction.
4 Lerman Y, Hirschberg A. Clinical problems in organophosphate insecticide poisoning: the use of a computerised information system. Fundam Appl Toxicol 1984;4:s209-14.

5 Gallo MA, Lawryk NJ. Organic phosphorous pesticides. In Hayes WJ Jnr, Laws ER Jnr, eds. Handbook of pesticide toxicology. London: Academic Press, 1991;2:917-1123.

6 Durham WF, Gaines TB, Hayes WJ Inr. Paralytic and related effects of certain organic phosphorous compounds. American Medical Association Archives of Industrial Health 1956;13:326-30

7 Gaines TB. Acute toxicity of pesticides. Toxicol Appl Pharmacol 1969;14:515-34.

8 Senanayake N, Karalliedde L. Neurotoxic effects of organophosphorous insecticides: an intermediate syndrome. N Engl f Med 1987;316:761-3.

9 Niven KJM, Scott AJ, Hagen S, Waclawski ER, Lovett M, Cherrie B, et al. Occupational hygiene assessment of sheep dipping practice and processes. Edinburgh: Institute of Occupational Medicine, 1993. (Technical Memorandum Series Tm/93/03.)

10 Health and Safety Executive. Monitoring of workers exposed to organo-phosphorous pesticides. London: HSE, 1987. organo-phosphorous pesticide
(Guidance Note MS 17.)

11 Nutley BP, Cocker J. Biological monitoring of workers occupationally exposed to organophosphate pesticides. Pesticide Science 1993:38:315-22.

12 Ballantyne B, Marrs CT, eds. Clinical and experimental toxicology of organophosphates and carbamates. London Butterworth Heinemann, 1992.

13 Rasmusen WA, Jensen WA, Stein WJ, Hayes WJ Jnr. Toxicological studies of DDVP for disinfection of aircraft. Aerospace Medicine 1963;34:594-600.

14 Mason HJ Lewis PJ. Intraindividual variation in plasma and erythrocyte cholinesterase activities and the monitoring of uptake of organophosphate pesticides. F Soc Occup Med 1989;39:121-4.

15 Lewis PJ, Lowing RK, Gompertz D. Automated discrete kinetic method for erythrocyte acetylcholinesterase and plasma cholinesterase. Clin Chem 1981:27;926-9.

16 Nutley BP. Towards a biological monitoring strategy for organophosphate pesticides. Development of an analytical method for the measurement of dialkylphosphates in urine. Section Paper. London: Health and Safety Executive Research and Laboratory Services Division, Occupational Medicine and Hygiene Laboratories, 1991.

17 Jackson JR. Aromatic and aliphatic compounds. In: Raffle PB, Lee WR, McCallum RI, Murray R, eds. Hunters diseases of occupations. London: Hodder and Stoughton, 1987:331-41.

18 Whittaker M. Monographs in human genetics, vol 11, cholinesterase. London: Karger, 1986.

19 Coye MJ, Lowe JA, Maddy KJ. Biological monitoring of agricultural workers exposed to pesticides 1. Cholinesterase activity determinations. $F$ Occup Med 1986;28: 619-28.

20 Vorhaus LJ II, Kark RM. Serum cholinesterase in health and disease. Am f Med 1953;14:707-19.

21 Ebert F, Harbison RD, Zenz C. Occupational health aspects of pesticides: clinical and hygenic principles. In: Zenz C, ed. Occupational medicine, principles and practical applications, 2nd ed. Chicago: Yearbook Medical Publishers, 1988:662-700

22 Galbraith DA, Watts DC. Human erythrocyte acetylcholinesterase in relation to cell age. Biochem $\mathcal{f} 1981 ; 195$ 221-8.

23 Mason HJ, Waine EM, Stevenson AJ. Aging and spontaneous reactivation of human plasma cholinesterase activity after inhibition by organophosphorous pesticides. London: Health and Safety Executive Research and Laboratory Services Division, Occupational Medicine and Hygiene Laboratory Division, Occupational Medichemistry Section, 1992.

24 Coye MJ, Barnett PG, Midtling JE, Velasco AR, Romero P, Clements CL, et al. Clinical confirmation of organophosphate poisoning of agricultural workers. $A m \mathcal{F}$ Ind $\mathrm{Med}$ 1986;10:399-409.

25 Drevenkar V, Radic Z, Vasilic Z, Reiner E. Dialkylphosphorous metabolites in the urine and activities of esterases in the serum as biochemical indices for human absorption of organophosphate pesticides. 7 Toxicol Environ Health 1981;7:715-31.

26 Morgan DP, Hetzler HL, Slach EF, Lin LI. Urinary excretion of paranitrophenol and alkylphosphates following tion of paranitrophenol and alkylphosphates following ingestion of methyl or ethyl parathion by hur

27 Franklin CA, Fenske RA, Greenhalgh R. Correlation of urinary pesticide metabolite excretion with estimated dermal contact in the course of occupational exposure to guthion. f Toxicol Environ Health 1981;7:715-31.

28 United States Environmental Protection Agency. Health and environmental effects profile for diazinon. Cincinnat: EPA 1984

29 Meier EP, Dennis WH, Rosencrance AB, Randall WF, Cooper WJ, Warner MC. Sulfotepp: a toxic impurity in formulations of diazinon. Bull Environ Contam Toxicol 1979;23:158-64.

30 Dauterman WC. Biological and non-biological modification of organophosphorous compounds. WHO Bull 1971;44: of organ

31 Soliman SA, Sovocool GW, Curley A, Ahmed NS, El-Fiki S, El-Sebae AK. Two acute human poisoning cases resulting
from exposure to diazinon transformation products in from exposure to diazinon transformation
Egypt. Arch Environ Health 1982;37:207-12.

32 Radeleff RD. Veterinary toxicology. Philadelphia: Lea Febiger, 1964. 